\title{
Escritor-personagem e leitor cúmplice em Sérgio Sant’anna
}

\author{
Igor Ximenes Graciano
}

RESUMO: As narrativas de Sérgio Sant’Anna sugerem, pela exposição recorrente dos bastidores da criação literária (aqui entendida como gesto literário), que o discurso ficcional extrapola o espaço da literatura, repercutindo as relações dos indivíduos no "mundo real”. Em sua prosa é evidente a tentativa dos narradores de aproximarem o leitor para suas perspectivas, quando a narrativa assemelha-se a um jogo em que o prêmio é a cumplicidade deste a quem ela se dirige. Com isso, estende-se uma via de mão-dupla entre vida e imaginário, de modo que uma constitui e é constituída pelo outro. Como afirma Carlos Santeiro, personagem de Um romance de geração, trata-se das “possibilidades possíveis” do texto para além do texto, uma vez que o acordo entre narrador romanesco e leitor - e que sustenta o acontecimento literário - carrega muito dos pressupostos das diversas instâncias discursivas entre indivíduos, ficcionais ou não.

PALAVRAS-CHAVE: Ficção, escritor-personagem, leitor, cumplicidade.

ABSTRACT: Sérgio Sant'Anna's narratives suggest, by the recurring exposure of the behind the scenes of literary creation (understood here as a literary gesture), that the fictional discourse goes beyond the space of literature, reflecting the relationships of individuals in the "the "real world". In his prose, it is clear that the narrators attempt to bring the reader nearer to their perspectives, when the narrative is like a game where the prize is the complicity of the individual to whom it is addressed. Thus, a two-way track is created between life and the imaginary, so that one constitutes and is constituted by the other. As stated by Carlos Santeiro, a character on Um romance de geração, this is the "potential possibilities" of the text beyond the text, since the agreement between fictional narrator and reader - which supports the literary event - carries many of the assumptions of the several instances of discourse between individuals, fictional or not. KEYWORDS: Fiction, writer-character, reader, complicity.

\section{A ficção como uma teoria da leitura Ricardo Piglia}

\section{O último ato}

Se antes a encenação - o riso e a lágrima - transcorria no espaço do palco, sob a luz artificial, agora ela se espalha para além dos seus limites, quando os atores se despojam de suas personagens e finalmente colocam as máscaras de si, para que não se corra o risco de confusão, ou mesmo para que não se pense que estão enlouquecendo. Não. $O$ último ato prossegue pelas ruas e casas, apartamentos e marquises, bares e praças. Se há pouco o público se defendia do espetáculo em suas cadeiras, frontalmente desgarrados da cena, agora não há distinções, muito pelo contrário. Ao se defrontar com os atores no café do teatro, ou em qualquer outro ambiente, logo o espectador percebe que o palco se alargou indefinidamente, e que a encenação, antes restrita ao elenco da peça, tomou toda a paisagem, tornando a vida um jogo perigoso, porque não tão seguro quanto à

Doutorando em Literatura Comparada na Universidade Federal Fluminense - Niterói. Mestre em Literatura pela Universidade de Brasília. Contato: ixgraciano@gmail.com. 
circunscrição da fantasia. Reconhecendo que a ficção abarca todas as coisas, engendrando-as no limite incerto entre o dado e o imaginado, o espectador se expõe com suas máscaras possíveis, habitando as narrativas de Sérgio Sant’Anna, em riso e lágrima.

Esse passeio do espectador "fora" do espaço em que se dava o espetáculo ilustra a trajetória da crítica em relação aos agentes que compõem a literatura, indicando o mais recente dos seus diferentes enfoques: o leitor. Se antes, mais marcadamente durante o Romantismo, o ato interpretativo buscava a verdade genuína e insubstituível da voz autoral, chegando depois ao fetiche do "texto em si" com o advento das críticas imanentistas, agora o triângulo se fecha ao se levar em conta o papel do leitor nesse cenário.

De receptor passivo da voz autoral ou da essência decifrável do texto, o leitor foi alçado a elemento sem o qual nem a voz autoral nem o texto em si se realiza, afinal um livro fechado é letra morta, silêncio irreparável do que possa haver dentro ou fora do cânone. É como se, no meio do espetáculo da escrita, de repente a luz do palco fosse lançada para o público, acompanhando-o mesmo depois da encenação, a fim de iluminar cada movimento ou feição, transformando-o em protagonista involuntário.

Mas quais as consequências dessa inversão? Se é certo que o enfoque e o estudo sistematizado sobre o leitor constituiu uma novidade teórica em meados do século XX, não se pode falar o mesmo da produção literária, mais especialmente a ficção, na qual ele muitas vezes é o protagonista ou alguém com quem o narrador dialoga diretamente. Ricardo Piglia entende que a investigação sobre o papel e a natureza do leitor é fundamental para a compreensão da literatura. Para ele, a pergunta "o que é um leitor?" constitui o principal questionamento da literatura, de modo que ela "não é externa a si mesma, é sua condição de existência. E a resposta a essa pergunta - para benefício de todos nós, leitores imperfeitos, porém reais - é um texto: inquietante, singular, sempre diverso" (PIGLIA, 2006, p. 25). Assim, entende-se que o leitor não está somente "fora" dos universos ficcionais, chegando ora a protagonizá-los, como personagem, ora atuando indiretamente, como espectador a quem a encenação se dirige. Seja como figura simbólica representada no espaço da ficção, seja como voyeur, o leitor é o ponto de convergência do gesto literário, encenando, ao mesmo tempo, as personas de avaliador e cúmplice, observador e observado.

Ao discutir o papel do escritor, a ficção de Sant'Anna fatalmente expressa seu confronto com o leitor, quando escreve e mostra-se a escrever para esse outro que lê. As motivações que levam à prática literária são avaliadas, nos casos mais extremos, pela voz de Sérgio Sant'Anna, personagem. A conduta crítica do Romantismo, que tem como fim a "verdade da voz autoral", parece obsoleta diante de um narrador que se justifica a cada parágrafo, expondo seus motivos e suas supostas intenções secretas. O jogo interpretativo, porém, não se tornou desnecessário, pelo contrário, ele ainda é preponderante nas imbricações da narrativa; o que mudou foi o conjunto de suas regras. O narrador-escritor de Sant'Anna se expõe enquanto esconde, finge que é sincero quando apenas deixa algumas pistas sobre o que de fato está oculto por debaixo do tapete de sua fala. Há sim uma "verdade do autor", no entanto ela é constituída à sombra do leitor, levando-se em conta suas possíveis desconfianças. Em resumo, os narradores de Sant’Anna jamais contam com uma interpretação ingênua. Legitimar-se, nem que seja declarando sua in- 
suficiência na representação do mundo e dos outros, é uma estratégia fundante de sua prosa. Ele pressupõe e se dirige a um leitor que não se entrega, ao leitor hostil.

Por isso o texto como exposição do gesto literário dá a ver, mais que o enredo e a forma, a lucidez do discurso ficcional sobre seus próprios procedimentos. A declaração da sua insuficiência sugere que pela prosa literária não só se narra (ou tenta narrar) o mundo e os outros, mas principalmente narra-se o empenho em narrá-los. Quando não suporta o peso e a veracidade do que se lhe apresenta na paisagem (aqui entendida como o conjunto dos contextos sociais), o escritor, se não a expressa, expõe sua tentativa de expressão, de modo que a escrita parece resultar mais do olhar sobre si do que da observação do mundo. Cogitando sobre a autoria desconhecida de um quadro, uma das personagens de "Homem sozinho numa estação ferroviária”, e que não por acaso é também o título do quadro objeto de especulações no conto, afirma que "os espelhos são interiores e projetam para o pintor um reflexo que contém simultaneamente a figura dele próprio e da paisagem onde se acha encerrado pelas recordações" (SANT'ANNA, 1997a, p. 388).

A motivação que leva ao gesto literário incide sobre o ofício criativo em si, o que faz com que o escritor se desvie por vezes dos movimentos percebidos na paisagem. Não se trata, porém, de autorrepresentação ou autobiografia pura e simples. Personagens de si, os narradores de Sant'Anna dizem indiretamente da condição de existência do discurso ficcional, que pressupõe uma cumplicidade almejada entre ele e o leitor, posto que o receptor da obra, a despeito das motivações e percalços que levaram à criação, procura o que nela há de significativo para ele próprio. Em linhas gerais, o fundamento da ficção se dá a meio caminho entre a escrita do texto (sua concepção) e a leitura (sua recepção), como em uma negociação contratual, quando cada uma das partes - contratante e contratado - busca para si os respectivos benefícios.

É importante não confundir, contudo, as instâncias humanas com as propriamente literárias, estas estabelecidas pelo texto. Segundo a conceituação de Umberto Eco, há uma clara distinção entre autor e leitor empíricos - que seriam, no caso, o próprio Sérgio Sant'Anna e seus eventuais leitores - do autor e leitor modelos. A realização do fenômeno literário, por assim dizer, depende de uma interação entre esses dois últimos, de modo que "o autor-modelo é uma voz que nos fala afetuosamente (ou imperiosamente, ou dissimuladamente), que nos quer a seu lado. Essa voz se manifesta como uma estratégia narrativa, um conjunto de instruções que nos são dadas passo a passo e que devemos seguir quando decidimos agir como o leitor-modelo" (ECO, 2006, p. 21). Se a leitura guarda várias interpretações, estas não são infinitas, já que se submetem, em diferentes graus, a uma intenção autoral identificável no texto, como as migalhas de pão deixadas no caminho por João e Maria, para que não se perdessem nas encruzilhadas da floresta.

A despeito de se aprofundar nos meandros da estética da recepção e suas deficiências, como as que demonstram Eagleton (1997) e Compagnon (1999), para quem ela somente substitui a figura do autor pela do leitor (no sentido de que reitera a intenção autoral como a verdade última do texto), as formulações de Eco interessam por evocarem o acordo tácito entre os envolvidos, afinal ambos compartilham do mesmo objeto, ainda que em perspectivas diversas. Ao autor interessa ser minimamente compreendido, o 
que significa dizer que o resultado de seu gesto depende da colaboração do leitor, sua anuência, já que a leitura não prossegue quando não o interessa de alguma maneira.

Levar em consideração a presença do leitor (seu olhar) desde a escrita é algo fundamental para a compreensão da prosa de Sant'Anna, uma vez que em suas narrativas se instaura uma trama de olhares que inevitavelmente extrapola o espaço da ficção, confundindo as fronteiras entre o real e o imaginário. Linda Hutcheon, ao analisar a tendência das narrativas pós-modernas em mesclar gêneros discursivos, conclui que "as fronteiras mais radicais que já se ultrapassaram foram aquelas existentes entre ficção e não-ficção e - por extensão - entre a arte e a vida" (1991, p. 27). Para Hutcheon, porém, "não existe nenhuma fusão simples, não problemática", em parte porque se cria uma instabilidade na relação com o leitor, afetando consideravelmente seu paradigma de recepção. Ao se expor (ainda que indiretamente) no corpo da narrativa literária, Sant’Anna lança para o enquadramento seguro da ficção a complexidade ilimitada da vida. Em contrapartida, sugere que a ficção adentra e constitui consideravelmente a vida, dando a ver que o último ato independe do palco, desdobrando-se dia após dia nas paisagens possíveis.

Ao tratar dos leitores-personagens de Jorge Luis Borges, que leem tudo como ficção, Piglia especula que "há uma certa inversão do bovarismo, sempre implícita em seus textos; não se lê a ficção como mais real do que o real, mas o real perturbado e contaminado pela ficção" (PIGLIA, 2006, p. 28). Em certa medida, o mesmo ocorre em parte da prosa de Sant'Anna, na qual a personagem Sérgio Sant'Anna se confunde com o escritor de carne e osso, o que faz com que se relativize consideravelmente o distanciamento que deveria haver entre o eu que fala do que assina a obra. Expondo-se parcialmente na personagem que engendra a partir de sua imagem e semelhança, o escritor atenua as fronteiras da ficção, atentando o leitor para o espaço incerto que permeia a invenção e a vida factível.

\section{A escrita de si para o outro}

Em seu retorno a São Paulo em um voo especial - que trazia as vítimas de um desastre aéreo e seus parentes -, o narrador de "O voo da madrugada" é visitado por uma jovem com a qual se abraça durante um período da viagem, adormecendo em seus braços. O insólito do episódio está em que a jovem não se encontrava entre os passageiros, não sendo identificada após a aterrissagem. A despeito do que motivou aquela aparição, ou do que ela se tratava, o narrador, ao chegar em casa, depara-se, como se não bastasse, com uma cena ainda mais improvável, seu duplo:

Sentado em minha cama, a fitar-me com uma placidez sorridente, na qual julguei detectar uma ponta de ironia, estava um homem - se assim devo nomeá-lo - que, pela absoluta implausibilidade da situação e pela indefinição etária de seus traços, demorei alguns segundos - se é que podia medir o tempo - para identificar como sendo eu próprio. Como se fosse possível eu me repartir em dois, aquele que viajava e aquele que aguardava tranquilamente em casa, ou talvez, num espaço fora do tempo. (SANT’ANNA, 2003, p. 26) 
Como o duplo de Borges ${ }^{2}$, o narrador de Sant’Anna é surpreendido ao encontrar-se consigo próprio. A diferença, entretanto, está que no conto do escritor argentino o confronto se deu entre fases (faces) distintas do mesmo indivíduo - o velho e o jovem. $O$ embate com o diferente, ainda que fosse ele próprio, leva à resignação: "comprendí que no podíamos entendernos" (BORGES, 1998, p. 17).

Encontrar seu duplo no espaço da ficção, mais do que a descrição de um fenômeno sobrenatural, significa a expressão da escrita de si comum a todo texto. Escrever é inscrever-se de alguma maneira, introjetando na linearidade do discurso as marcas incontestes da subjetividade. O narrador de "O voo da madrugada" não por acaso é um escritor. Aliás, ele faz questão de marcar muito bem a diferença da escrita pragmática, de "prosaicos relatórios", das escritas inventivas que, "ainda que quase sempre malditas, retiram sua razão de ser de si mesmas" (SANT'ANNA, 2003, p. 27). Com isso, ao conceber o outro, o narrador inevitavelmente se inventa, chegando inclusive a declarar isso como prova de sua natureza ficcional. Ainda que possua a voz que realiza o fato narrado, esta não se sobrepõe às outras, como se as representasse em uma instância mais vinculada ao real. No espaço do conto toda existência é forjada: "antes de ser esta uma história de espectros - acrescento com uma gargalhada, pois uma súbita hilaridade me predispõe a isso -, é uma história escrita por um deles" (SANT'ANNA, 2003, p. 28).

A declarada natureza ficcional do narrador extrapola o âmbito dos elementos que constituem a narrativa, principalmente quando ele toma as formas e o nome do escritor, como se este adentrasse o espaço do texto, ficcionalizando-se. Para Ernesto Sábato, “é só com máscaras, no carnaval e na literatura, que os homens se atrevem a dizer suas (tremendas) verdades últimas" (SÁBATO, 1982, p. 43). No caso, Sant’Anna usa a máscara de Sant'Anna, ou de um similar seu, a fim de expor não necessariamente "suas verdades últimas" enquanto indivíduo, e sim para escancarar a condição do escritor, "seus fantasmas", conforme outra expressão de Sábato.

Nesse entrecaminho (cruzamento?) da invenção e do dado, vislumbra-se o ponto fundamental do discurso inventivo, quando se sugere que esse dualismo é desde sempre ingênuo, porque descarta o papel do imaginário na constituição dos indivíduos "reais". Afinal, por mais concreta que seja a existência, ela sempre se constituirá dessa matéria improvável que é a ficção, que molda o mundo e os seres a partir do imaginário, como que prenunciando suas possibilidades. De outro lado, pode-se questionar sobre o que, em se tratando do gesto literário, o motiva de fato, senão aquilo que ele tem de vital para o "mundo aqui de fora"? Considerando essa vitalidade, o que a caracterizaria? Embora identifique e discorra sobre uma pretensa função do escritor, Barthes acredita que a característica fundamental do seu trabalho é a intransitividade, uma vez que sua palavra é

uma sobre-palavra, o real lhe serve apenas de pretexto (para o escritor, escrever é um verbo intransitivo); disso decorre que ela nunca possa explicar o mundo, ou pelo menos, quando ela finge explicá-lo é somente para aumentar sua ambigüidade: a ex$^{-}$ plicação fixada numa obra (trabalhada) torna-se imediatamente um produto ambíguo

Aqui me refiro ao conto “El otro", que abre a coletânea El libro de arena, onde um alter ego de Borges se depara com seu duplo 50 anos mais jovem, com quem acaba por ter uma conversação. 
do real, ao qual ela está ligada com distância; em suma, a literatura é sempre irrealista, mas é esse mesmo irrealismo que lhe permite fazer freqüentemente boas perguntas ao mundo - sem que essas perguntas possam jamais ser diretas. (BARTHES, 2003, p. 33-34)

Antepondo a figura do escritor à do escrevente, este último imbuído de uma noção pragmática da escrita, no sentido de que ele pretende interferir de maneira mais incisiva sobre a realidade, Barthes ressalta a ambiguidade literária, que interfere indiretamente nas paisagens sociais, ainda que de modo aprofundado, "lançando boas perguntas". Se a princípio as proposições do teórico francês parecem um elogio um tanto deslumbrado, quando não ingênuo, da literatura, é importante ressaltar que ela se volta para a busca de sua especificidade, seu papel no mundo contemporâneo. Por que, afinal, conceber ficções?

A necessidade de ficção (e que responde de certa forma à pergunta acima formulada) vem junto com o que Sábato considera um de seus paradoxos: um exílio da realidade que acaba por iluminá-la, revelando-a a partir das implicações do jogo narrativo (SÁBATO, 1982, p. 130). Na mesma linha de pensamento, Umberto Eco conclui que "a obra de ficção nos encerra nas fronteiras de seu mundo e, de uma forma ou de outra, nos faz levá-la a sério" (ECO, 2006, p. 84). Ou seja, a motivação do gesto literário - que advém por sua vez dessa necessidade irreprimível de expressão pela escrita inventiva - está na tensão latente entre o que se apresenta como ficção e o que atinge como a verdade substantiva do real.

Se a História é uma narrativa que se vincula ou se quer vinculada aos fatos ocorridos no passado, ou se pretende ler os fatos do passado à luz de perspectivas diferenciadas a história do Brasil contada sob o ponto de vista dos escravos africanos, por exemplo -, essa revisão se dá sobre um panorama histórico comum, de acontecimentos comuns encadeados no tempo e que resultaram no mundo como hoje o conhecemos. Ainda que no relato histórico ou no ensaio o escrevente (conforme a terminologia de Barthes) utilize a imaginação criadora, cultivando a palavra trabalhada, seu gesto jamais é intransitivo, pois aponta para algo pré-existente à natureza do texto, motivando-o e sobre ele atuando, na intenção (muitas vezes inconfessada) de “desvelar" o objeto em análise.

o gesto literário, por seu lado, mais especificamente o discurso ficcional, pressupõe uma liberdade a princípio absoluta, como se o escritor se lançasse cegamente para o abismo da imaginação, tecendo mundos à sua maneira, indiferente às paisagens que o circundam. No entanto, bem se sabe da angústia da escrita inventiva, e Sérgio Sant’Anna é um caso exemplar dessa classe de escritores que não sofrem somente no processo secreto da criação, como também expõem, na própria escrita, esse processo, dando a ver que o gesto literário é desgastante justamente pela liberdade que ele proporciona diante da crueza irredutível da "vida como ela é". Ainda segundo Barthes, a palavra intransitiva da escrita literária pressupõe um certo sentido de responsabilidade, afinal, "para o escritor, a verdadeira responsabilidade é a de suportar a literatura como um engajamento fracassado, como um olhar mosaico sobre a Terra Prometida do real" (BARTHES, 2003, p. 35).

Em "Um concerto de João Gilberto no Rio de Janeiro" o narrador, no caso Sérgio Sant'Anna, pretende escrever um conto sobre o concerto que o músico não deu na capital carioca, retornando para Nova Iorque sem executar um acorde sequer. A ideia é que o concerto de João Gilberto foi o seu não concerto, o que resulta em um conto que, 
inspirado no episódio, constitui-se de uma não narrativa, ao menos em termos de uma narrativa tradicional linear. Projetando-se ficcionalmente, Sant'Anna relativiza os limites da criação artística, dizendo que aquilo que se encontra "do lado de dentro" da arte, e que lhe é próprio, não se aliena do que ocorre ou existe "do lado de fora”. A responsabilidade do escritor advém da percepção de que o processo artístico não se desgarra do mundo factível, e sim que o mundo factível e seus habitantes se constituem em grande medida das ficções que consomem ou que forjam para si, vivendo o real como resultado realizado do imaginário. O escritor é resultado de sua ficção, sendo geralmente consciente disso, quando percebe que "entrar no espaço branco da página é também como entrar em cena” (SANT’ANNA, 1997a, p. 306). A cena, no caso, é a representação do ambiente social em sua totalidade; o escritor em cena como em vida, inscrevendo-se.

Em "A mulher-cobra", a existência é diretamente ligada ao ato de narrar, mais que isso, misturando-se com a própria narrativa: "como sabem, ser testemunha é para mim uma questão de sobrevivência. Essa coisa que me fascina nos acontecimentos, fazendo com que eu, narrando-os, possa sentir-me existente, ao menos por algumas horas, antes que novas formas informes voltem a debater-se dentro de mim" (SANT'ANNA, 1997a, p. 378). Esse trecho é revelador de algumas implicações do gesto literário, uma vez que coloca as cartas na mesa: narrar é existir. Repare-se, entretanto, que ao mencionar um recorte temporal ("algumas horas"), o narrador sugere que a sua existência coincide naturalmente com o ato da leitura, o que se torna ainda mais evidente com o uso de expressões do tipo “como sabem”, dirigidas ao leitor. Quando busca publicar-se, lançando-se aos olhos do público, o escritor acaba por confessar que escrever não é um gesto tão intransitivo quanto parece, afinal o gesto literário se estende ao outro, sem o qual não há existência a ser percebida, como se a voz e a perspectiva de quem narra à despeito do leitor se esvaíssem como sonhos esquecidos.

Qualquer relato busca o diálogo, contando com certa dose de cumplicidade do receptor. O sentimento de insuficiência do gesto literário emerge da incapacidade de traduzir a esse outro que lê a expressão desejada, caso contrário, resta o horror das "formas informes”. Tal necessidade de alcance, portanto, se assemelha muito às correspondências:

Escrever é pois “mostrar-se”, dar-se a ver, fazer aparecer o rosto próprio junto ao outro. E deve-se entender por tal que a carta é simultaneamente um olhar que se volve para o destinatário (por meio da missiva que recebe, ele sente-se olhado) e uma maneira de o remetente se oferecer ao seu olhar pelo que de si mesmo lhe diz. De certo modo, a carta proporciona um face-a-face. A reciprocidade que a correspondência estabelece não se restringe ao simples conselho ou ajuda; é ela a do olhar e do exame. (FOUCAULT, 2006, p. 150-151)

Esse face-a-face descrito por Foucault é nada mais que o encontro entre autor e leitor, pois também nas narrativas literárias há o exame mútuo entre as partes, claro que em posições diferenciadas, afinal o autor se lança para um leitor hipotético, quando busca atingi-lo através da escrita, tateando pelo espaço da ficção. Ao leitor, porém, nada resta que não seja o texto, de maneira que, para que se garanta a existência dessa voz autoral, deve-se aceitá-la em sua dicção e estilo, caso contrário o pacto da leitura jamais se realiza. 
Em se tratando de prosa de ficção, o pacto se dá em termos muito diferentes do que normalmente se daria em uma carta. A correspondência se legitima por uma pretensa autenticidade, de modo que a voz que fala remete diretamente a uma pessoa identificável. No conto "Uma carta”, Beatriz escreve para Carlos depois de um relacionamento furtivo, rememorando todo o ocorrido e percebendo de antemão o assombro de seu receptor: "talvez você se espante de eu me expor assim, depois de tão pouco tempo em que verdadeiramente estivemos juntos" (SANT’ANNA, 1997a, p. 587). Na carta de Beatriz, tudo é narrativa e confissão, desde os primeiros olhares e sensações até a percepção do outro no momento em que se conheceram. Tudo como numa carta, ou como deveria ser, quando pelas palavras procura-se conceber a si próprio, flagrando-se em seus sentimentos, registrando e expondo-os ao outro. O desfecho da carta, no entanto, é a negação de seu propósito, que deveria ser um diálogo efetivo entre duas pessoas:

Esta carta então apócrifa, egoísta, orgulhosa, que se quer uma essência das cartas, utópica e abstrata como uma melodia vermelha, entoada por uma mulher que talvez nem seja engenheira, talvez a louca em trajes fétidos no pátio do asilo e que se chama Jussara, mas assina Beatriz como quem se veste de princesa para um amante inventado; que inventa ainda uma cachoeira, uma casa e até seu prefeito; esta louca que talvez nem seja mulher, mas um homem solitário em seu quarto acanhado e que constrói para si uma amante louca em nome de quem remete a si mesmo ou ao léu uma carta que tenha a duração escrita de uma noite. (SANT’ANNA, 1997a, p. 605)

Tudo pode ser invenção, inclusive a identidade do narrador. Ao quebrar-se o contrato firmado pela correspondência, o que antes valia como verdade cai por terra, sobrando nada mais que algumas possibilidades ficcionais. O eu que fala se esconde sob a máscara de algum outro, seja ele quem for, narrando o que lhe convém narrar, por algum motivo. Se na carta há uma relação mais simples (e mais ingênua) entre destinatário e remetente, já que a princípio o face-a-face de ambos seria mais franco, o mesmo não ocorre com as narrativas literárias, em que o autor se esconde sob o discurso do narrador, falando através dele. Tal fala, contudo, tem de ser convincente, pois o que prende o leitor à ficção é o que ela carrega das paisagens e paradigmas sociais os quais ele testemunha e participa, pressupondo-se que "os mundos ficcionais são parasitas do mundo real" (ECO, 2006, p. 89).

A necessidade do narrador de atrair o leitor para a sua perspectiva se repete em boa parte das composições de Sant'Anna, a ponto de elas tratarem obsessivamente do processo criativo cujo fim é sempre atingir alguém. Se o escritor e seu ofício são o foco, o que se discute na verdade é o papel da ficção, sua especificidade frente a outras modalidades discursivas. O gesto literário, enquanto gesto, tem naturalmente uma amplitude pública, no sentido de que, desde a intimidade da escrita, todas as instâncias da literatura atuam sobre o escritor - das paisagens que o inspiraram e servem de cenário até o leitor, que insone observa seu trabalho, às vezes pigarreando, para que nunca se esqueça de sua presença. A propósito, Dominique Maingueneau afirma que toda obra, "direta ou indiretamente, só fala de seu autor, obrigando o destinatário a se interessar por ele” (MAINGUENEAU, 1996, p. 143). 
Se escrever é inscrever-se, a narrativa literária é necessariamente um olhar lançado para fora do espaço da ficção. Entre os mundos factíveis e os imaginados há uma interpenetração latente, quando se percebe que o ato de contar uma história é mais que uma história contada, mas também a maneira como as pessoas se dão conta da existência, organizando-a numa sequência compreensível de fatos, nós e resoluções. O leitor participa do gesto literário contrapondo seu gesto interpretativo, dando ao texto mais do que o autor expressa, pois a palavra intransitiva da prosa de ficção, quando lida, é logo alçada para o plano das realizações, talvez porque a narrativa, assim como o mito, tem como função "encontrar uma forma no tumulto da experiência humana" (ECO, 2006, p. 93). Tal como escrever, ler não é entregar-se ao delírio da invenção, pelo contrário. O empreendimento da leitura é comprometedor, já que, inevitavelmente, as fábulas carregam os vícios e virtudes daqueles que as engendraram. Em uma frase: ler é implicar-se na escrita do outro.

\section{Trinta pares de olhos}

O ponto fundamental, e mesmo o mais controverso, na relação do escritor com o leitor está em se atribuir ou não total liberdade ao criador. Até que ponto o escritor está preso a uma malha social que delimita sua voz, fazendo com que seu gesto seja uma resposta mais ou menos esperada diante dos parâmetros formais e éticos de seu tempo? Não seria isso um retorno a uma perspectiva determinista, com todos seus perigos e simplificações? Ao se colocar o leitor como participante implícito do gesto literário, não haveria aí a corrupção do papel do autor, na medida em que este conceberia seus mundos ficcionais à sombra da expectativa do público, o que caracterizaria certo comprometimento com a lógica do mercado?

Essas e outras perguntas são pertinentes, porém podem guardar o conservadorismo que questionam. Aliás, em se tratando de qualquer postura crítica, a deficiência mais grave é a falta do que Hayden White (2001) denomina autorreflexibilidade, ou seja, a desconfiança em relação a seus próprios pressupostos. Trazendo à baila a voz do inimigo, ilumina-se o que até então era tido como inquestionável, para não dizer dogmático, relativizando-o. A literatura de Sant'Anna toma como princípio esse dizer entre aspas, seja imitando o outro, seja imitando-se a si, a fim de olhar-se no espelho e perceber (e dar a perceber) seus tiques e cacoetes.

O riso em Sant’Anna não é motivado pelo simples prazer do escárnio, ao contrário, ri-se a contragosto um riso amargo, autoirônico, algumas vezes emblemático da postura cética de um narrador à beira do silêncio, mas que insiste em não calar. Se a personagem de Carlos Santeiro, em Um romance de geração, admite que escreve "para comer as mulheres” (SANT’ANNA, 1981, p. 20), é porque não está mais à vontade no papel tradicional do escritor como "o artista ascético e solitário que a tudo observa com seus olhares neutros para escrever o drama do seu edifício, do seu bairro, sua cidade e, 'quiçá', da sua geração" (SANT’ANNA, 1981, p. 21).

Esse desconforto, no entanto, está no nível da expressão literária, não se refletindo diretamente na relação do sujeito social Sérgio Sant'Anna com sua escrita. Ainda que haja alguma autorrepresentação e o gesto literário surja como tema, não se está ex- 
pondo a intimidade criativa "verídica", o que levaria em conta as horas intermináveis de trabalho e as páginas descartadas durante a realização das narrativas. Ao se afirmar que o leitor está presente desde sempre no gesto literário, na verdade reitera-se uma preocupação muito mais ampla e aprofundada quanto à recepção dos textos, o que não implica em concessões estéticas ou mercadológicas que almejam "ganhar” parcelas do público, ou que se apresentem como respostas "naturais" aos anseios e preocupações de um determinado tempo histórico.

Em seu aspecto formal, a obra de Sant’Anna não deixa de imprimir rigor estilístico e liberdade na constituição das narrativas, isso à custa de uma demanda do artista frente a seus anseios expressivos. A preocupação com o leitor, nesse caso, advém de um certo fatalismo contratual identificável nos textos, os quais sugerem que os jogos narrativos repercutem as relações sociais que se dão para além dos recantos ficcionais. Se há liberdade, ela não é completa, pois toda expressão busca a cumplicidade do interlocutor, caso contrário não seria expressão. Por mais vanguardista e desgarrado de convenções que seja, o artista inescapavelmente se dirige a uma comunidade, mesmo que essa comunidade seja ele próprio (ou quem ele julga seus pares), sua vaidade e pretensão de atingir zonas nunca antes exploradas.

Essa procura pela cumplicidade é evidenciada no conto "A aula”. O protagonista, um professor "empírico", diante da tarefa de ministrar a aula inaugural do curso de "Estética e Filosofia da Comunicação", defronta-se com "trinta pares de olhos", os alunos, quando percebe que "ultrapassara o ponto sensato de fuga, só lhe restando seguir em frente, ainda que aos tropeções, sobre a corda bamba do raciocínio" (SANT’ANNA, 1997a, p. 544). Como em um espaço cênico, o professor se autointerpreta aos olhos da turma a fim de prender sua atenção: "ele fez uma pequena pausa, aproveitando para acender outro cigarro e, por detrás dos óculos escuros, dar uma rápida passada de olhos nos alunos, a fim de verificar se estavam atentos (e estavam), e continuou" (SANT’ANNA, 1997a, p. 548).

Impossível, aqui, não aproximar a relação professor/aluno com a que se estabelece entre escritor e leitor. Apesar das diferenças fundamentais, é notável a semelhança quanto ao propósito comum do professor e do escritor diante da atenção anônima da turma ou dos leitores. Assim como o professor se arma de estratégias para conquistar o interesse dos alunos na aula inaugural, o escritor, por meio do narrador, se aventura no espaço branco da página a fim de arrebatar o receptor implícito de sua escrita, aquele a quem ele direciona um olhar furtivo, prevendo suas reações quando tenta seduzi-lo para seu artefato: a obra. Antevendo a pergunta de um dos alunos sobre a chamada, após o término de uma aula triunfante, o professor conclui que "não iria ter chamada, porque a um artista só era possível uma pedagogia: a da sedução, ainda que através do choque” (SANT’ANNA, 1997a, p. 556).

Esse artista que se vê obrigado a seduzir é, talvez mais do que nunca, o narrador contemporâneo, momento em que o espaço do literário é desmistificado, onde a entrega total do leitor à ficção foi aos poucos sendo corroída por dentro, como se a fábula desbaratasse sua própria condição de fábula. Contrariamente ao realismo do século XIX, que escamoteava a presença do narrador, nos séculos XX e XXI sua textura torna-se bem mais porosa:

Hoje - cada vez mais - os escritores realizam o processo inverso, interferem na narrativa a fim de ressaltar a presença daquele que fala, localizando-o em seu contexto e 
prerrogativas. [...] A consciência de que toda obra é artifício e de que toda perspectiva é deturpadora exige do leitor o reconhecimento da intermediação, sem o que o jogo narrativo não pode começar. o que não quer dizer que o interesse pelo drama humano deva ser anulado em função da arquitetura do texto. (DALCASTAGNÈ, 2005, p. 15-16)

Por ser questionado, ou, o que dá no mesmo, por perder a total credibilidade que antes lhe era atribuída, o narrador se transforma paradoxalmente na grande estrela dos estudos literários, na medida em que é ele o motor de todas as implicações da narrativa. De seu lado, o leitor acaba por se ver como coestrela desse mesmo espetáculo, já que o gesto literário nunca se completa sem a sua participação. Se antes o empenho interpretativo se concentrava inteiramente na fictio, hoje é quase inevitável vislumbrar as paisagens ficcionais sem pensá-las como uma negociação, um tecido tramado que se estende entre aquele que escreve e o leitor, vértice fundamental das possibilidades do texto.

\section{Depois do último ato}

Depois do último ato segue ainda um próximo ato. Não há mais como fugir do espaço cênico, uma vez que antes, no que seria o último ato, constatou-se que o palco se espalhara indefinidamente, não restando nada mais que não fosse encenação. O leitor, como se sabe, deixou de ser um espectador, quando finalmente viu-se sujeito efetivo do espetáculo da escrita, também ele um protagonista, percebendo que cada gesto ou pose no enquadramento da ficção é forjado para seu deleite, sua aprovação. Assustado e ao mesmo tempo envaidecido por tamanha atenção, ele segue pelas ruas do romance até encontrar, não por acaso, seu progenitor, Sérgio Sant’Anna, também andando por ali como quem nada quer, sorrindo a alguns transeuntes, ignorando outros, enfim, vivendo como qualquer cidadão na cidade de São Sebastião do Rio de Janeiro, entre bares e paisagens colhidas na memória.

Não é preciso ser muito esperto para notar que Sant'Anna só parece andar como quem nada quer, que na verdade nem os transeuntes, nem as paisagens são aleatórios, apesar de parecerem, de tão convincentes. Ainda assim, o leitor prossegue e até arrisca uma conversa com alguns daqueles seres irreais, entrando nos bares e se embriagando nos cenários concebidos pelo autor, que não longe dali acompanha o andamento de sua farsa.

Porém, a menos que seja louco ou que tenha enlouquecido no decorrer de sua jornada narrativa adentro, o leitor sabe que a encenação, mesmo quando ocorre além dos limites do palco, misturando-se aos fatos e pessoas da vida real, continua sendo encenação; que uma coisa é interpretar um papel alheio e outra muito diferente é interpretar o papel de si, dia após dia; que apesar da ficção impregnar todas as coisas, há coisas que efetivamente ocorrem fora de sua alçada. Mesmo que o imaginário constitua a vida em diversos níveis, levar tal assertiva ao pé da letra é entregar-se ao desvario do Quixote. Por isso é quase irresistível entrar e deleitar-se nas paisagens ficcionais, vivenciando-as e mesmo se perdendo por seus meandros, afinal na ponta do gesto literário está ele próprio, o leitor, a se lançar em cada entrecho da narrativa, reconhecendo-se nesse outro que lhe fala. 
As possibilidades possíveis do texto estão nos jogos interpretativos que se estabelecem durante a leitura, nas fissuras da narrativa. Em Um crime delicado, o crítico teatral Antô ${ }^{-}$ nio Martins, na ânsia de desvendar o que verdadeiramente um bilhete mandado por Inês queria dizer, já que ele não conseguia se recordar do que havia acontecido entre os dois na noite anterior, devido a uma amnésia alcoólica, procede da seguinte maneira:

Bem, ali estava eu a decifrar os subentendidos possíveis nos espaços, entrelinhas e na pontuação de um bilhete, o que se repete no texto cheio de curvas que agora escrevo, também pleno de interrogações. Ao escrevê-lo, percebo como é difícil fazê-lo quando não se tem os "pré-textos", ou espetáculos, que servem de apoio, bengala, a esses cautelosos que são os críticos. Percebo que a escrita nos distancia, quase sempre, das coisas reais, se é que existe uma realidade humana que não seja a sua representação, ainda quando apenas pelo pensamento, como numa peça teatral a que não se deu a devida ordem, aliás inexistente na realidade. (SANT’ANNA, 1997b, p. 50)

O trecho carrega muito das principais implicações da leitura, pois descreve um leitor profissional - trata-se de um crítico -, que explora as possibilidades de um bilhete não no que ele diz diretamente, mas no que pode guardar de revelador daquele que o escreveu. O que torna o jogo complexo, do ponto de vista das imbricações narrativas, é que também ele, Antônio Martins, é um escritor, mas cuja escrita é reflexo direto do modo como ele lê ("que se repete no texto cheio de curvas que agora escrevo, também pleno de interrogações”). Ao se justificar, explicando o que motiva sua dicção por vezes enviesada, Antônio Martins acena para o leitor, que diante de seu texto pode proceder da mesma maneira, escarafunchando as bordas da narração, abrindo as gavetas e olhando pelas frestas do discurso, ávido por encontrar algum sentido subterrâneo.

Como um Casmurro em dias pós-modernos, Martins conta sua história na tentativa de reconstituí-la desapaixonadamente, no intuito de saber se o processo movido contra ele, no qual é acusado de ter estuprado Inês, foi produto de uma série de eventos premeditados por ela e o artista plástico Vitório Brancatti. Sendo crítico, ele entende que sua escrita deve ser desmistificadora, a fim de que se desvele a essência das coisas, sua verdade subjacente: "Ora, ser crítico é um exercício da razão diante de uma emotividade aliciadora, ou de uma tentativa de envolvimento estético que devemos decompor, para não dizer denunciar, na medida do possível com elegância" (SANT'ANNA, 1997b, p. 19). A pretensão ou o dever de fugir da sedução estética (a "coisa emocional"), dando a ver o mecanismo das composições, diz da ambiguidade inerente ao relato de Martins, que discorre sobre o "caso Inês" - por vezes o esmiuçando como um crítico diante de uma obra qualquer - como se fosse possível analisar friamente uma montagem em que ele próprio fosse o diretor.

A despeito de ser ou não possível recordar/escrever desapaixonadamente, o relato busca a colaboração de quem o recebe, como se através desse olhar exterior fosse possível ligar os pontos e trazer à tona a verdade insubstituível dos fatos. Tal olhar, contudo, é impossível, já que "a escrita nos distancia, quase sempre, das coisas reais, se é que existe uma realidade humana que não seja a sua representação" (SANT’ANNA, 1997b, p. 50). Ao narrar, Martins nunca dá todos os elementos para o desvendamento do episódio, ou porque não consegue, 
ou porque não lhe interessa. A imagem do biombo no quarto de Inês na noite do suposto estupro, "com suas propriedades de velar e sugerir" (p. 25), denuncia o jogo proposto ao leitor, do qual ele participa no momento em que lê, perscrutando a voz que lhe narra.

Outra vez Umberto Eco: "em um texto narrativo, o leitor é obrigado a optar o tempo todo" (ECO, 2006, p. 12). Desse pressuposto é que advém a necessidade do narrador - e do autor - de ganhar a cumplicidade do leitor, já que este pode tomar rumos na interpretação que não interessam a ele, ou que sequer eram esperados. Para um narrador tão comprometido quanto Martins, essa cumplicidade é mais que o motor da narrativa, sendo mesmo seu tema. Em Um crime delicado, o confronto entre o crítico e o artista é apenas um dos enfoques, talvez o menos relevante, servindo tão somente como mote à exploração do gesto literário em suas possibilidades. O narrador-crítico Antônio Martins representa o arquétipo das narrativas de Sant'Anna, que não se bastando como farsa, recaem na necessidade de elucidá-la, justificando-se ou mostrando sua maquinaria, enquanto puro artefato. Ao comentar a obra que Brancatti expôs na Alemanha, após o término do processo criminal, Antônio Martins dá termo à narrativa submetendo-a ao juízo do leitor:

E para escrever, como de fato escrevo, sobre tal obra, expondo-a, e o que existencialmente a circundou, em todas as suas contradições, truques, ambiguidades e divergências, jamais poderia lográ-lo no espaço crítico de um jornal e sim gerando minha própria e pequena obra. Que por ela tentem avaliar melhor a de Brancatti - e consequentemente julgar a mim, tanto criminal quanto profissional e, ouso dizer, literariamente - os leitores e também os críticos, meus pares. (SANT’ANNA, 1997b, p. 132)

O crítico é despojado de seu papel (sua proteção), que é ler para avaliar o outro, quando se regozijava na tarefa de decifrar as personas por detrás das obras, expondo-as. Inscrevendo-se literariamente, Martins não apenas se revela como personagem, mas também como escritor, o que o torna consideravelmente mais frágil. Se a atividade crítica diz do crítico, ao menos quando se pode constatar suas preferências e objeções, na prosa de ficção (que no caso se apresenta como depoimento), essa exposição se escancara drasticamente, pois não existe nada mais denunciador do que a obra de arte, que em suas nuances e contradições faz emergir máscaras inconfessáveis. Sob o olhar avaliador de seus leitores potenciais, Martins apresenta sua "própria e pequena obra" como uma necessidade.

Assim, o gesto literário é desnudado aos olhos do público, como um espetáculo. A preocupação com a escrita ficcional é antiga, tanto que se pode pensar que jamais se produziu literatura - ao menos em sua acepção moderna - sem cogitar acerca dos seus fundamentos, suas consequências. A narrativa de lugares e seres imaginários defronta-se com o que não há, mas que é como se fosse, e que por isso mesmo arrebata e faz sentido. Ainda que de uma forma ou de outra o escritor sempre fale de si, ele nunca fala para si, voltando-se para o mundo dos outros, quando aproveita as frestas de luz da realidade para iluminar parcialmente suas paisagens ficcionais. Entre a letra e as coisas, o gesto literário se justifica pelo que nele há de irremediavelmente atrelado à concretude da vida, realizando-se na leitura. 


\section{Referências Bibliográficas}

BARTHES, Roland. “Escritores e escreventes” In: Crítica e verdade. Trad. Leyla Perrone-Moisés. São Paulo: Perspectiva, 2003.

BORGES, Jorge Luis. “El otro” In: El libro de arena. Madrid: Alianza Editorial, 1998.

COMPAGNON, Antoine. "O Mundo" In: O Demônio da Teoria: Literatura e senso comum. Trad. Cleonice Paes Barreto Mourão. Belo Horizonte: Editora UFMG, 1999.

DALCASTAGNÈ, Regina. Entre fronteiras e cercado de armadilhas: problemas de representação na narrativa brasileira contemporânea. Brasília: UnB; Finatec, 2005.

EAGLETON, Terry. Teoria Literária: Uma Introdução. Trad. Waltensir Dutra. São Paulo: Martins Fontes, 1997.

ECO, Umberto. Seis passeios pelos bosques da ficção. Trad. Hildegard Feist. São Paulo: Companhia das Letras, 1994.

FOUCAULT, Michel. O que é um autor? Trad. António Fernando Cascais e Eduardo Cordeiro. Lisboa: Nova Vega, 2006.

HUTCHEON, Linda. "Teorizando o pós-moderno: rumo a uma poética” In: Poética do pós-modernismo: história, teoria, ficção. Trad. Jayme Salomão. Rio de Janeiro: Imago Editora, 1991.

MAINGUENEAU, Dominique. Discurso literário. São Paulo: Contexto, 2006.

WHITE, Hayden. "Introdução" In: Trópicos do discurso: Ensaios sobre a crítica da cultura. Trad. Alípio Correio de Franca Neto. São Paulo: EDUSP, 2001.

PIGLIA, Ricardo. O último leitor. Trad. Heloisa Jahn. São Paulo: Companhia das Letras, 2006. SÁBATO, Ernesto. O escritor e seus fantasmas. Trad. Janer Cristaldo. Rio de Janeiro: Francisco Alves, 1982.

SANT’ANNA, S. Um romance de geração. Rio de Janeiro: Civilização Brasileira, 1981. . Contos e novelas reunidos. São Paulo: Companhia das Letras, 1997a. Um crime delicado. São Paulo: Companhia das Letras, 1997b. . O voo da madrugada. São Paulo: Companhia das Letras, 2003.

ArTigo ReCEBIDO EN: 31 jul. 2012

ArTigo ACEITO EM: 26 set. 2012

Referência eletrônica: Graciano, Igor. O leitor cúmplice em Sérgio Sant'anna. Revista Criação \& Crítica, n. 9, p. 81-94, nov. 2012. Disponível em: <http://www.revistas.usp.br/criacaoecritica>. Acesso em dd mmm aaaa. 